\title{
AIR STRIPPING FOR AMMONIA REMOVAL FROM LANDFILL LEACHATE IN VIETNAM: EFFECT OF OPERATION PARAMETERS
}

\author{
Tran Tien Khoi ${ }^{1,2}$, Tran Thi Thanh Thuy ${ }^{2,3}$, Nguyen Thi Nga ${ }^{2,3}$, Nguyen Nhat Huy ${ }^{2,3}$, Nguyen Thi Thuy ${ }^{12^{*}}$ \\ ${ }^{1}$ International University, ${ }^{2}$ Vietnam National University Ho Chi Minh City \\ ${ }^{3}$ Ho Chi Minh City University of Technology (HCMUT)
}

\begin{tabular}{|c|c|}
\hline ARTICLE INFO & \multirow{12}{*}{$\begin{array}{l}\text { ABSTRACT } \\
\text { Leachate is the wastewater from landfill that contains various pollutants at high } \\
\text { concentrations. The treatment of leachate requires a complicated wastewater } \\
\text { treatment system including chemical, physico-chemical, biological, and } \\
\text { advanced treatment processes. The high ammonia concentration of leachate } \\
\text { usually causes inhibition for microorganism in biological treatment. Therefore, } \\
\text { it is necessary to remove ammonia from the leachate to lower concentrations to } \\
\text { make it suitable for further treatment processes. In this study, we designed an air } \\
\text { stripper for removal of ammonia in both synthetic and leachate wastewater. The } \\
\text { effects of pH, hydraulic loading rate (HLR), gas/liquid }(\mathrm{G} / \mathrm{L} \text { ) ratio, and } \\
\text { recirculation of liquid on the ammonia stripping efficiency were investigated. } \\
\text { The results show that rising pH from } 9 \text { to } 12 \text { increased significantly ammonia } \\
\text { removal efficiency, irrespective of the changes of G/L or HLR. At both HLR of } \\
57.6 \text { and } 172.8 \mathrm{~m}^{3} / \mathrm{m}^{2} . \text { day, increase G/L ratio led to the enhancement of removal } \\
\text { efficiency, getting the highest value of } 56 \% \text { at HLR of } 172.8 \mathrm{~m}^{3} / \mathrm{m}^{2} . \text { day, pH } 12 \text {, } \\
\text { and G/L of } 728 \text {. Furthermore, recirculating of leachate improved the stripping } \\
\text { efficiency of ammonia up to } 99.0 \% \text { after three hours with the output concentration } \\
\text { of } 25.2 \mathrm{mg} / \mathrm{L} \text {. The results from this study hence proved the effectiveness of air } \\
\text { stripping as a pre-treatment process for ammonia removal from landfill leachate } \\
\text { and suggested suitable operating conditions. }\end{array}$} \\
\hline Received: 08/02/2021 & \\
\hline Revised: $28 / 5 / 2021$ & \\
\hline Published: 31/5/2021 & \\
\hline & \\
\hline KEYWORDS & \\
\hline Leachate & \\
\hline Landfill & \\
\hline Air stripping & \\
\hline & \\
\hline Gas transfer & \\
\hline Ammonia & \\
\hline
\end{tabular}

\section{XỬ LÝ AMONI TRONG NƯỚC RỈ RÁC TÙ̉ BÃI CHÔN LẤP TÁI VIÊT NAM BẰNG PHƯƠNG PHÁP TÁCH KHÍ: ẢNH HƯỞNG CỦA CÁC THÔNG SỐ VẬN HÀNH}

\section{Trần Tiến Khôi ${ }^{1,2}$, Trần Thị Thanh Thủy ${ }^{2,3}$, Nguyễn Thị Nga ${ }^{2,3}$, Nguyễn Nhật Huy ${ }^{2,3}$, Nguyễn Thị Thủy ${ }^{12^{*}}$}

${ }^{1}$ Trưòng Đại học Quốc tế, Đại học Quốc gia Thành phố Hồ Chí Minh,

${ }^{3}$ Trường Đại học Bách khoa Thành phố Hồ Chí Minh

\begin{tabular}{|c|c|}
\hline THÔNG TIN BÀI BÁO & TÓM TÁ́T \\
\hline Ngày nhận bài: 08/02/2021 & \multirow{7}{*}{$\begin{array}{l}\text { Nước rỉ rác là nước thải từ bãi chôn lấp chứa các thành phần ô nhiễm ở nồng độ } \\
\text { cao. Do đó, việc xử lý nước rỉ rác cần một hệ thống phức tạp bao gồm các quá } \\
\text { trình hóa học, hóa lý, sinh học và xử lý nâng cao. Nồng độ cao của amoniac } \\
\text { trong nước rỉ rác ngăn cản sự phát triển của các vi sinh vật trong xử lý sinh học } \\
\text { nên cần loại bỏ amoni xuống nông độ thấp hơn, tạo điều kiện thuận lợi cho các } \\
\text { quá trình xử lý tiếp theo. Trong nghiên cứu này, tháp tách khí để loại bỏ amoni } \\
\text { từ nước thải tổng hợp và nước rỉ rác đã được thiết kế và thử nghiệm. Ânh hưởng } \\
\text { của pH, tải trọng thủy lực (HLR), tỷ lệ khí/lỏng }(\mathrm{G} / \mathrm{L}) \text {, và thời gian tuần hoàn }\end{array}$} \\
\hline & \\
\hline & \\
\hline Ngày đăng: 31/5/2021 & \\
\hline & \\
\hline TÙ̀ KHÓA & \\
\hline Nước rỉ rác & \\
\hline Bãi chôn lấp & lên hiệu quả tách amoni đã được nghiên cứu. Kết quả cho thấy việc tăng $\mathrm{pH}$ từ 9 \\
\hline & tới 12 đã tăng hiệu quả xử lý amoni dù hệ thống vận hành ở những tỷ lệ $\mathrm{G} / \mathrm{L}$ hay \\
\hline 1 acn Kml & HLR khác nhau. Tại HLR bằng 57.6 và $172.8 \mathrm{~m}^{3} / \mathrm{m}^{2}$.ngày, tăng tỷ lệ G/L nâng \\
\hline Truyền khôi & cao được hiệu quả xử lý, đạt $56 \%$ với HLR ở $172.8 \mathrm{~m}^{3} / \mathrm{m}^{2}$.ngày, pH 12 , và $\mathrm{G} / \mathrm{L}$ \\
\hline Amoni & 728. Việc tuần hoàn nước rỉ rác đã cải thiện đáng kể hiệu quả tách amonia, lên \\
\hline & tới $99.0 \%$ sau ba giờ, đạt nồng độ amoni đầu ra là $25.2 \mathrm{mg} / \mathrm{L}$. Như vậy, kết quả \\
\hline & $\begin{array}{l}\text { từ nghiên cứu này đã chứng minh hiệu quả của phương pháp tách khí trong tiền } \\
\text { xử lý amoni từ nước rỉ rác và đề xuất được các điều kiện vận hành phù hợp. }\end{array}$ \\
\hline
\end{tabular}

DOI: https://doi.org/10.34238/tnu-jst.3997

\footnotetext{
* Corresponding author. Email: ntthuy@hcmiu.edu.vn
} 


\section{Introduction}

Leachate is a type of wastewater generated in landfills, formed by leakage of rainwater into landfills or due to the available moisture of waste accumulated in the bottom layer of landfill and seepage through the soil. In general, there are four main components in leachate, including (i) organic compounds such as dissolved organic substances, volatile fatty acids (acetic, propionic, butyric compounds), fulvic acid, humic acid, etc.; (ii) main inorganic ions: $\mathrm{Ca}^{2+}, \mathrm{Mg}^{2+}, \mathrm{Na}^{+}, \mathrm{K}^{+}$, $\mathrm{NH}_{4}^{+}, \mathrm{Fe}^{2+}, \mathrm{Mn}^{2+}, \mathrm{Cl}^{-}, \mathrm{SO}_{4}^{2-}$, and $\mathrm{HCO}^{3-}$; (iii) heavy metals: $\mathrm{Cd}^{2+}, \mathrm{Cr}^{3+}, \mathrm{Cu}^{2+}, \mathrm{Pb}^{2+}, \mathrm{Ni}^{2+}$, and $\mathrm{Zn}^{2+}$; (iv) xenobiotic organic compounds: aromatic compounds, phenols, pesticides, chlorinated aliphatics, plastics, etc. and oil-derived components of fuel: benzene, toluene, xylene, etc. Among these components, ammonia nitrogen is one of the pollutants of concern because its concentration is very high $(800-5210 \mathrm{mg} / \mathrm{L})$, even in leachate from old landfills [1]. The total ammonia nitrogen (TAN) up to $1000 \mathrm{mg} / \mathrm{L}$ can inhibit microbial activity, reducing the effectiveness of the biological based processes [2], [3]. Because it is generated from waste, leachate is very toxic and difficult to be handled, causing serious environmental pollution. It is known that with a certain amount of leachate absorbed into the soil, this wastewater can contaminate groundwater while if it follows into the canal, the water environment can be deteriorated. Therefore, leachate must be thoroughly treated before being discharged into the environment. To solve the problem of pollution from leachate, many technologies have been studied and applied, such as biological (anaerobic and aerobic), chemical-biological (Fenton-anaerobic-aerobic, and stripping-anaerobicaerobic), physical, chemical oxidation, and membrane technologies.

Several studies have reported that air stripping is successful in removing ammonia from landfill leachate and many other wastewaters [4]-[9], such as those from the fertilizer industry [10], pig slurry [11], [12], anaerobic digestion effluent [13], [14] or source-segregated food waste [15]. The effectiveness of ammonia removal obtained in these studies was in the range of 90 to 99\%. Ozturk et al. [6] used air-stripping to treat ammonia in leachate at the optimum $\mathrm{pH}$ of about 10,11 , and 12 . The results showed that after 2 hours of aeration, the ammonia removal was $72 \%$ at $\mathrm{pH} 12$ while it was nearly $20 \%$ at $\mathrm{pH} 10$ and 11 . Under continue aeration for the next 24 hours, the ammonia removal was at 45,80 , and $85 \%$ after 6,12 , and 17 hours, respectively [6]. In addition, Marttinen et al. [16] also used air-stripping tower with a 1.1-liter PVC column $(6 \mathrm{~cm}$ in diameter and $40 \mathrm{~cm}$ high) filled by plastic materials, to remove ammonia from leachate. Experiments were performed at $\mathrm{pH} 11$ at temperatures of 6,10 , and $20{ }^{\circ} \mathrm{C}$ and a flowrate of 2 or $10 \mathrm{~L} / \mathrm{h}$ for 0,6 , and 24 hours. In the 24-hour test, the highest ammonia removal of $89 \%$ was achieved at $\mathrm{pH} 11,20{ }^{\circ} \mathrm{C}$ and a gas flowrate of $10 \mathrm{~L} / \mathrm{h}$ [5]. Furthermore, most studies on air stripping relied on small stripping units in which air was bubbled at flow rates of 1.2 to $300 \mathrm{~L} / \mathrm{h}$ and only a small volume of leachate (0.8-4 L) was treated [5]-[7], [11], [17]-[19]. The ratio of $\mathrm{G} / \mathrm{L}\left(\mathrm{m}^{3} / \mathrm{m}^{3}\right)$ varied for each reference which was 50-150 [9], 45-200 [20], 1250 to 2000 [21], 3480 [22], and 2000-6000 [23].

In Vietnam, different technologies for ammonia removal from landfill leachate have been investigated, including partial nitrification and denitrification in SBR [24], chemical precipitation [25] for Nam Son landfill leachate, combining the anoxic and attached growth processes at Phuoc Hiep landfill [26], completely autotrophic nitrogen-removal over nitrite - SBR process for Go Cat Landfill leachate [27], electrocoagulation and bio-filter for Nam Son Leachate [28], [29], and Fenton process followed by coagulation for Quang Hanh landfill [30]. Though the application of air stripping for ammonia removal in leachate has been reported from some research around the word, such research is rarely found in Vietnam, except for one report with limited information about the roles of respective treatment processes of $\mathrm{pH}$ adjustment with $\mathrm{CaCO}_{3}$, air stripping, activated sludge, coagulation using $\mathrm{FeCl}_{3}$, Fenton oxidation, sand filtration, and chlorine disinfection processes in Phuoc Hiep and Go Cat landfills [31]. Therefore, the 
objective of this study was to apply a pilot air stripping tower with Kaldnes packing material for removal of ammonia from synthetic leachate and the leachate collected from Go Cat Landfill.

\section{Materials and methods}

\subsection{Synthesis of wastewater and leachate collection}

Artificial wastewater was made from ammonium chloride $\left(\mathrm{NH}_{4} \mathrm{Cl}\right)$ in tap water at different $\mathrm{NH}_{4}{ }^{+}$concentrations. Real leachate was collected from Go Cat Landfill (Binh Hung Hoa Ward, Binh Tan District, Ho Chi Minh City). According to [27], this leachate is characterized as an old landfill leachate which was closed since 2007. The concentrated leachate was taken directly from the collection tank while the leachate diluted by rainwater was collected at storage pond.

\subsection{Air stripping unit}

An air stripping tower was designed with a $2 \mathrm{~m}$ high tube and a diameter of $0.09 \mathrm{~m}$ (Table 1). Kaldnes rings $(25 \times 25 \mathrm{~mm})$ made of Polyvinyl Chloride with a specific surface area of $250 \mathrm{~m}^{2} / \mathrm{m}^{3}$ were used as the packing material in the tower. The height of packing material was $1.80 \mathrm{~m}$. The tower was operated in batch mode at room temperature. As shown in Figure 1, the wastewater was conveyed by a dosing pump from the wastewater tank to the top of the tower. At this point the leachate was distributed evenly through the packing material and simultaneously contacted with air stream driven from the outside by an air blower. The treated wastewater was collected in a tank and its ammonia concentration was measured. In state\#3 (Table 2), the treated wastewater was recirculated back to the inlet while samples were regularly taken for ammonia analysis.

Table 1. Air stripping tower parameters

\begin{tabular}{lcc}
\hline Parameter & Unit & Value \\
\hline Diameter & $\mathrm{m}$ & 0.097 \\
Height & $\mathrm{m}$ & 2 \\
Height of packing material & $\mathrm{m}$ & 1.8 \\
Air blower & & \\
$\quad \quad$ Flow & $\mathrm{m}^{3} / \mathrm{h}$ & 3200 \\
$-\quad$ Power & $\mathrm{HP}$ & 2 \\
$\quad$ Pressure column & $\mathrm{Pa}$ & 1000 \\
Water pump & & \\
$-\quad$ Pressure column & $\mathrm{mH}_{2} \mathrm{O}$ & 2.5 \\
$-\quad$ Flow & $\mathrm{m}^{3} / \mathrm{h}$ & 40 \\
\hline
\end{tabular}

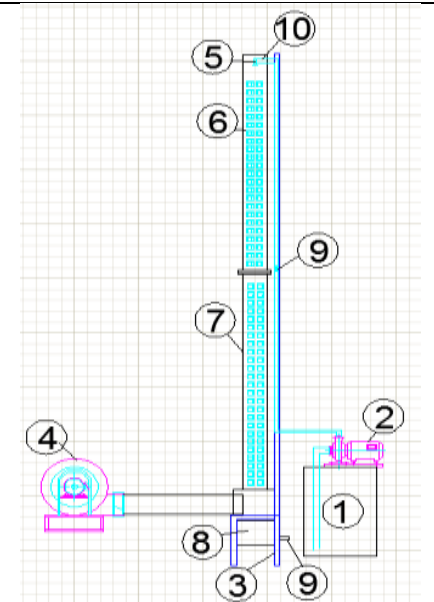

Figure 1. Schematic diagram of the air stripping tower: (1) wastewater tank, (2) dosing pump, (3) frame, (4) air blower, (5) wastewater distribution system, (6) packing material, (7) column, (8) treated wastewater tank, (9) treated wastewater outlet, and (10) wastewater inlet 


\subsection{Operating the tower}

During the operation, it is necessary to control parameters $\mathrm{pH}$ and gas/liquid ratio $(\mathrm{G} / \mathrm{L})$ so that $\mathrm{NH}_{4}{ }^{+}$in wastewater can be converted into $\mathrm{NH}_{3}$ gas. $\mathrm{pH}$ of leachate was adjusted to $9,10,11$, and 12 by slowly adding $30 \% \mathrm{NaOH}$ solution. The $\mathrm{pH}$ raising process must take place slowly to prevent rising $\mathrm{NH}_{3}$ too fast. $\mathrm{G} / \mathrm{L}$ was controlled by air and water flowrates in which water flowrate was adjusted by throttle valve while air flowrate was monitored by an anemometer.

Table 2. Operation modes of model

\begin{tabular}{|c|c|c|c|c|c|}
\hline Stage & $\begin{array}{l}\text { Type of } \\
\text { wastewater }\end{array}$ & $\begin{array}{l}\text { Liquid flowrate } \\
\text { (L/min) }\end{array}$ & $\begin{array}{l}\text { G/L ratio } \\
\left(\mathbf{m}^{3} / \mathbf{m}^{3}\right)\end{array}$ & $\begin{array}{l}\text { Average } \mathrm{NH}_{4}{ }^{+}{ }_{\text {in }} \\
(\mathrm{mg} / \mathrm{L})\end{array}$ & pH \\
\hline \multirow[t]{2}{*}{ Stage \#1 } & $\begin{array}{l}\text { Synthetic } \\
\text { wastewater }\end{array}$ & \multirow{2}{*}{$\begin{array}{l}\mathrm{Q}=0.3(\mathrm{~L} / \mathrm{min}) \\
(\mathrm{HLR}=57.6 \\
\left.\left(\mathrm{m}^{3} / \mathrm{m}^{2} . \text { day }\right)\right)\end{array}$} & \multirow[t]{2}{*}{$\mathrm{G} / \mathrm{L}=1802$} & $\begin{array}{l}3300,3000,1400, \\
500\end{array}$ & \multirow{2}{*}{$\begin{array}{l}\mathrm{pH}: 9,10,11, \\
12 .\end{array}$} \\
\hline & Leachate & & & $4032,3606,3405$ & \\
\hline \multirow{2}{*}{ Stage \#2 } & Leachate & $\begin{array}{l}\mathrm{Q}=0.3(\mathrm{~L} / \mathrm{min}) \\
(\mathrm{HLR}=57.6 \\
\left.\left(\mathrm{m}^{3} / \mathrm{m}^{2} . \text { day }\right)\right)\end{array}$ & $\begin{array}{l}\mathrm{G} / \mathrm{L}=936 \\
\mathrm{G} / \mathrm{L}=1630 \\
\mathrm{G} / \mathrm{L}=2185\end{array}$ & 3780 & $\begin{array}{l}\mathrm{pH}: 9,10,11, \\
12 .\end{array}$ \\
\hline & Leachate & $\begin{array}{l}\mathrm{Q}=0.9(\mathrm{~L} / \mathrm{min}) \\
(\mathrm{HLR}=172.8 \\
\left.\left(\mathrm{m}^{3} / \mathrm{m}^{2} . \text { day }\right)\right)\end{array}$ & $\begin{array}{l}\mathrm{G} / \mathrm{L}=312 \\
\mathrm{G} / \mathrm{L}=543 \\
\mathrm{G} / \mathrm{L}=728\end{array}$ & 3780 & $\begin{array}{l}\mathrm{pH}: 9,10,11, \\
12 .\end{array}$ \\
\hline \multirow{3}{*}{ Stage \#3 } & $\begin{array}{l}\text { Synthetic } \\
\text { wastewater }\end{array}$ & \multirow{3}{*}{$\begin{array}{l}\text { Recirculating } 15,30 \\
\min , 1,2 \text { and } 3 \mathrm{~h} ; \\
(\mathrm{HLR}=172.8 \\
\left.\left(\mathrm{m}^{3} / \mathrm{m}^{2} . \text { day }\right)\right)\end{array}$} & \multirow{3}{*}{$\mathrm{G} / \mathrm{L}=728$} & 3080 & pH: 12 \\
\hline & Leachate & & & 2520 & pH: 12 \\
\hline & Leachate & & & 442 & Initial pH (7.65) \\
\hline
\end{tabular}

*HLR: hydraulic loading rate

Three stages of operation were designed as given in Table 2 . The stage\# 1 was conducted in order to find the relation between input $\mathrm{NH}_{4}{ }^{+}$concentrations (in both synthetic and real leachate), $\mathrm{pH}$ and removal efficiency. For the stage \#2, effect of two hydraulic loading rates (57.6 and 172.8 $\left(\mathrm{m}^{3} / \mathrm{m}^{2}\right.$.day)) and different $\mathrm{G} / \mathrm{L}$ ratios on ammonia removal efficiency from real leachate was evaluated. In final stage (stage \#3), the tower was operated at optimum values of HLR, G/L, pH found from previous stages and the liquid phase was recirculated at different periods of time (15 and 30 minutes; 1, 2 and 3 hours). Total liquid volume in this stage was $5 \mathrm{~L}$ for both synthetic wastewater and leachate.

\subsection{Chemicals and parameters analysis}

$\mathrm{NH}_{4} \mathrm{Cl}$, acid boric, acids, and bases used in this study were purchased at analytical grade. $\mathrm{pH}$ of wastewater was measured by Hanna Hi 8424 while the air flowrate was measured by an anemometer (Manometer Testo 435). Ammonia concentration in wastewater was analyzed according to Standard Methods 4500 NH3 B with duplicates for each analysis.

\section{Results and discussion}

\subsection{Effect of $\mathrm{pH}$ and initial $\mathrm{NH}_{4}{ }^{+}$concentration on $\mathrm{NH}_{4}{ }^{+}$removal efficiency}

Relationship between $\mathrm{pH}$, initial ammonia concentration, and efficiency of ammonia removal in artificial wastewater and leachate is illustrated in Figure 2. As can be seen from Figure 2(a), $\mathrm{NH}_{4}{ }^{+}$remove efficiency was increased obviously when $\mathrm{pH}$ increased and initial $\mathrm{NH}_{4}{ }^{+}$ concentration reduced. The highest efficiencies achieved at $\mathrm{pH}$ of 12 were 79, 70, 64, and 48\%, corresponding to the initial concentrations of 500, 1400, 3000 and $3300 \mathrm{mg} / \mathrm{L}$. According to reaction (1), this trend is reasonable because of rising $\mathrm{pH}$ led to the shift of the equilibrium of the reaction to produce more $\mathrm{NH}_{3}$ into gas phase.

$$
\mathrm{NH}_{4}^{+} \leftrightarrow \mathrm{NH}_{3}+\mathrm{H}^{+}
$$



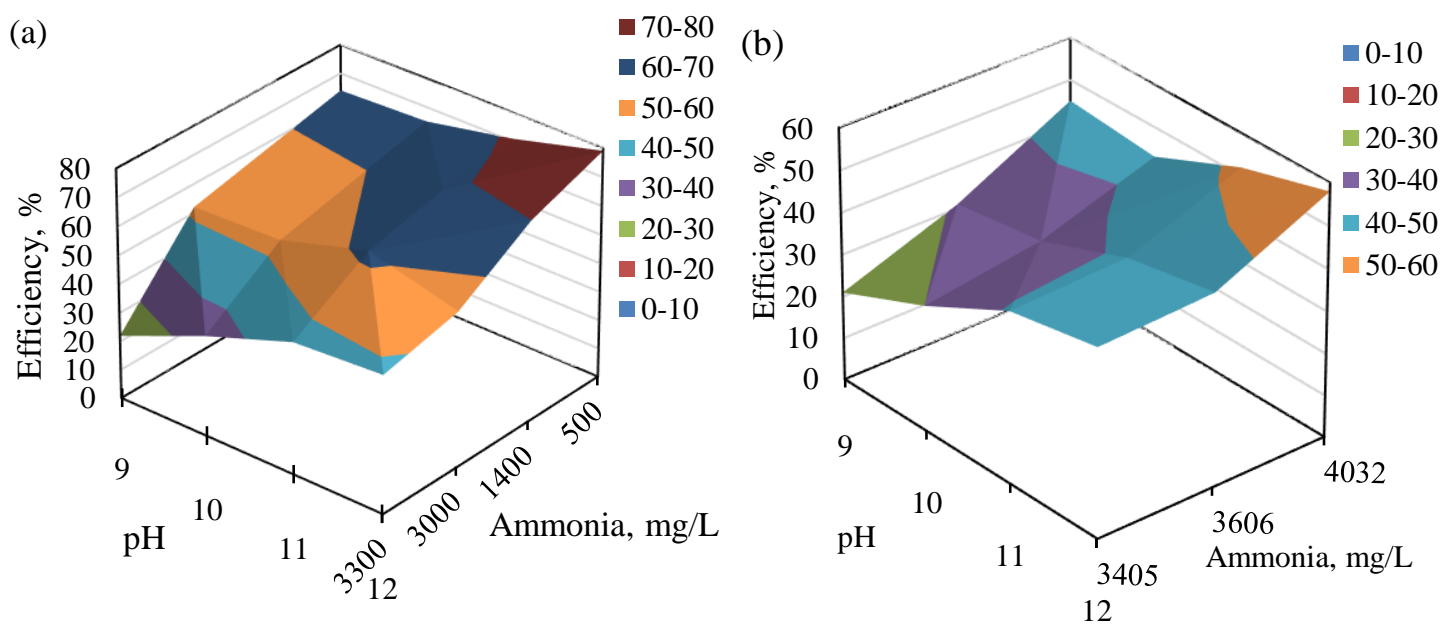

Figure 2. Relationship between $\mathrm{pH}$, initial ammonia concentration, and efficiency of ammonia removal in (a) artificial wastewater and (b) leachate

The dependence of removal efficiency on $\mathrm{pH}$ of leachate was similar to that of synthetic wastewater, with the highest amount of $\mathrm{NH}_{4}{ }^{+}$striped out at $\mathrm{pH} 12$. This optimum $\mathrm{pH}$ was consistent with the results of $\mathrm{pH}$ value found by Ozturk, et al. [6] and Marttinen, et al. [16]. However, increasing initial $\mathrm{NH}_{4}{ }^{+}$concentration of leachate from 3405, 3606 and $4032 \mathrm{mg} / \mathrm{L}$ resulted in the increasing of removal efficiency from 45,46 , and $58 \%$ at $\mathrm{pH} 12$, respectively. This trend differed from that of synthetic wastewater which can be explained based on the free ammonia amount available in leachate but not in synthetic wastewater. As calculated via the equation (2) [32], leachate contained about $1-5 \%$ of free ammonia (FA) and the leachate with a higher ammonia concentration contains a higher FA content which was easily released at the $\mathrm{pH}$ of greater than 9. Therefore, the leachate with higher input concertation of $\mathrm{NH}_{4}{ }^{+}$could achieve a higher removal efficiency.

$$
\mathrm{FA}=\frac{\mathrm{C}_{\mathrm{NH}_{4}^{+}} \times 10^{\mathrm{pH}}}{\frac{\mathrm{k}_{\mathrm{b}}}{\mathrm{k}_{\mathrm{w}}}+10^{\mathrm{pH}}}
$$

Where $\mathrm{C}_{\mathrm{NH}_{4}^{+}}$is ammonia concentration in leachate and $\frac{\mathrm{k}_{\mathrm{b}}}{\mathrm{k}_{\mathrm{w}}}=\exp \left(\frac{6,344}{273+\mathrm{t}}\right)$

\subsection{Effect of hydraulic loading rate and gas/liquid ratio on $\mathrm{NH}_{4}{ }^{+}$removal efficiency}

The results achieved from the operation of stage \#2 are illustrated on Figure 3. This experiment was conducted with two hydraulic loading rates (HLR) of 57.6 and $172.8 \mathrm{~m}^{3} / \mathrm{m}^{2}$.day, $\mathrm{pH}$ ranged from 9 to 12 , at different $\mathrm{G} / \mathrm{L}$ ratios. To increase $\mathrm{G} / \mathrm{L}$ ratio, we used a fixed wastewater flowrate while increased air flowrate (Table 2).

In consistent with the results from Section 3.1, the increase of $\mathrm{pH}$ from 9 to 12 significantly increased the removal efficiency of $\mathrm{NH}_{4}{ }^{+}$, irrespective of the changes of $\mathrm{G} / \mathrm{L}$ or HLR, getting the highest values at $\mathrm{pH} 12$. Under $\mathrm{pH} 12$ and the HLR of $57.6 \mathrm{~m}^{3} / \mathrm{m}^{2}$.day, increase $\mathrm{G} / \mathrm{L}$ ratio from 936 to 1630 led to the increase of removal efficiency, i.e. from 40 to $54 \%$. This is explained based on the Equation (3) [23]. Accordingly, when G/L increases, concentration of ammonia in the output $\left(\mathrm{C}_{\mathrm{e}}\right)$ will reduce or removal efficiency will increase. At this point, the working line shifts to the equilibrium line. However, the removal efficiency was unchanged when we further increased $\mathrm{G} / \mathrm{L}$ ratio from 1630 to 2815 (i.e. 54 and 54\%, respectively). 


$$
(\mathrm{G} / \mathrm{L})=\left(\mathrm{P}_{\mathrm{T}} / \mathrm{H}\right) \times\left(\mathrm{C}_{0}-\mathrm{C}_{\mathrm{e}}\right) / \mathrm{C}_{0}
$$

Where $\mathrm{H}$ is Henry's constant for ammonia, $\mathrm{P}_{\mathrm{T}}$ is total pressure, $\mathrm{C}_{0}$ and $\mathrm{Ce}$ is the input and output concentrations of ammonia, $\mathrm{G} / \mathrm{L}$ is the minimum ratio of gas and liquid.
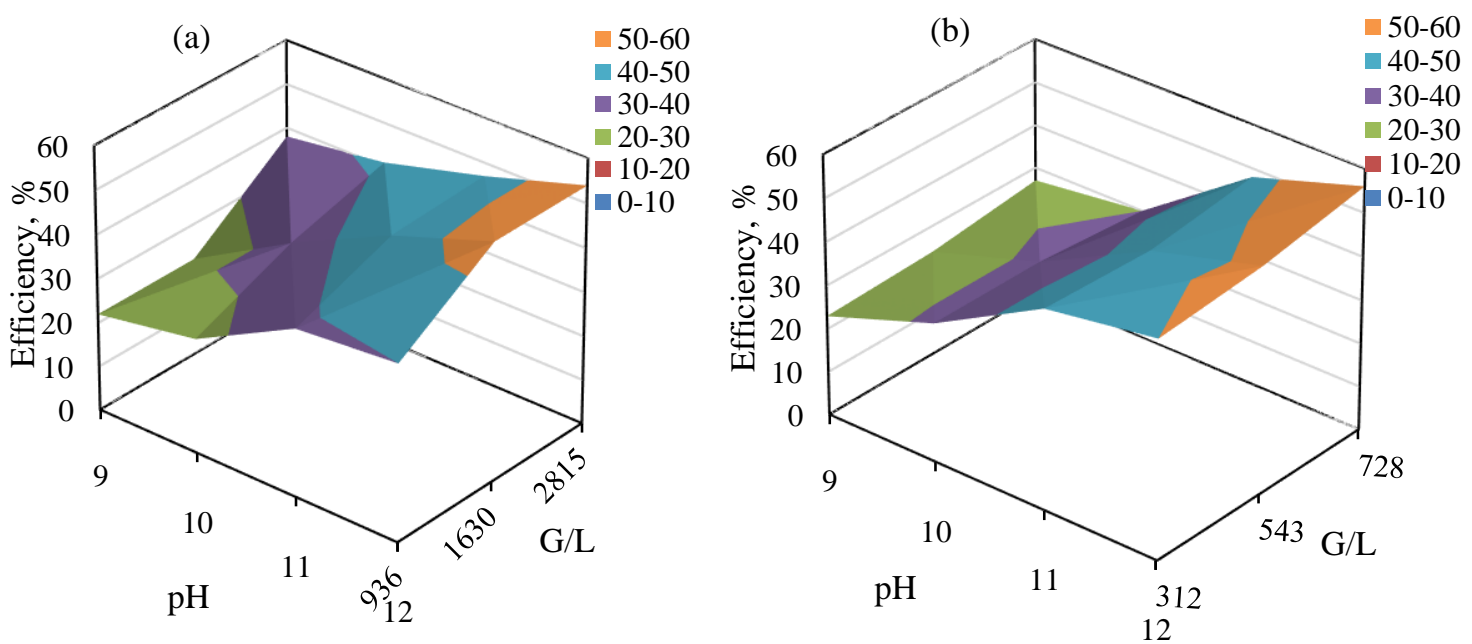

Figure 3. Relationship between $p H, G / L$, and efficiency at (a) $Q=0.3 \mathrm{~L} / \mathrm{min}, H L R=57.6 \mathrm{~m}^{3} / \mathrm{m}^{2}$.day and (b) $Q=0.9 \mathrm{~L} / \mathrm{min}, H L R=172.8 \mathrm{~m}^{3} / \mathrm{m}^{2}$.day

For the case of HLR of $172.8 \mathrm{~m}^{3} / \mathrm{m}^{2}$.day and G/L ratio of 312,543 and 728 , the removal efficiency was slightly changed from 50,52 , to $56 \%$, respectively, which is in consistent with the results of $[13,21]$. We hence selected HLR of $172.8 \mathrm{~m}^{3} / \mathrm{m}^{2}$.day, G/L ratio of 728 at $\mathrm{pH} 12$ due to the induced highest removal efficiency and wastewater treatment capacity. The G/L ratio of 728 in this study was higher than those from [9] (i.e. 50-150), [20] (i.e. 45-200) but smaller than the values applied in [21] (i.e. 1250-2000), [22] (i.e. 3480), and recommended in [23] (i.e. 20006000).

\subsection{Effect of recirculation on $\mathrm{NH}_{4}{ }^{+}$removal efficiency}

The results from the previous sections showed that the $\mathrm{NH}_{4}{ }^{+}$removal efficiency from the air stripping tower ranged from $48-79 \%$ for synthetic wastewater and $45-58 \%$ for leachate. To enhance the stripped amount of ammonia, recirculation of wastewater $(5 \mathrm{~L})$ was applied. As can be seen from Figure 4, operation with the artificial wastewater at initial $\mathrm{NH}_{4}{ }^{+}$concentration of $3080 \mathrm{mg} / \mathrm{L}$ could yield the efficiency from $90 \%$ at $15^{\text {th }}$ minute to $99 \%$ at the $120^{\text {th }}$ minute. At the same time, the $\mathrm{NH}_{3}$ concentration calculated in the gas phase decreased considerably from 1297 to $179 \mathrm{mg} / \mathrm{m}^{3}$. A similar trend of change in removal efficiency was found for the leachate containing $2520 \mathrm{mg} / \mathrm{L}$ of ammonia, from $81 \%$ at $15^{\text {th }}$ minute to $99 \%$ at $120^{\text {th }}$ minute. The $\mathrm{NH}_{4}{ }^{+}$ output concentration was $25.2 \mathrm{mg} / \mathrm{L}$ which is approximately equal to the allowable value in column B (i.e. $25 \mathrm{mg} / \mathrm{L}$ ) from national technical regulation on wastewater of the solid waste landfill sites (QCVN 25:2009/BTNMT). This efficiency is higher compared to those obtained from previous studies, e.g. $98 \%$ with the operation time of 4 to 9 days [20], 95.5\% for 3 hours [22]. During this period, the $\mathrm{NH}_{3}$ concentration dropped from 956 to $97 \mathrm{mg} / \mathrm{m}^{3}$, but was still higher than the value recommended in air quality - maximum allowable concentration of hazardous substances in ambient air (i.e. $0.2 \mathrm{mg} / \mathrm{m}^{3}$, TCVN 5938:2005) or the allowable value given in national technical regulation on industrial emission of inorganic substances and dusts (i.e. $50 \mathrm{mg} / \mathrm{m}^{3}$, column B, QCVN 19: 2009/BTNMT).

Though $\mathrm{pH}$ adjustment improved significantly the $\mathrm{NH}_{4}{ }^{+}$removal efficiency but this step consumes chemicals and requires the neutralization of the wastewater after the treatment to 
facilitate the next treatment steps. For the rainwater diluted leachate with a low concentration of $\mathrm{NH}_{4}{ }^{+}(442 \mathrm{mg} / \mathrm{L})$, we further tested the air stripping without $\mathrm{pH}$ adjustment and found the removal efficiency was $8,18,40,74$, and $91 \%$ at $15^{\text {th }}, 30^{\text {th }}$ minute, $1^{\text {st }}, 2^{\text {nd }}$, and $3^{\text {rd }}$ hour, respectively. Hence, recirculating the leachate could be considered as an effective pretreatment step improved the removal efficiency.

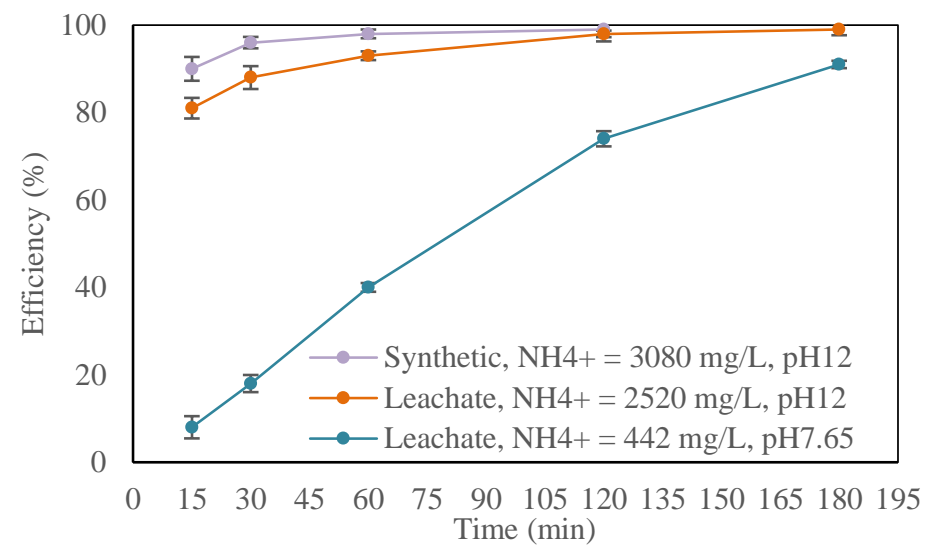

Figure 4. Effect of recirculation time on $\mathrm{NH}_{4}{ }^{+}$removal efficiency from artificial wastewater and leachate (error bars present standard deviations, $n=3$ )

\section{Conclusions}

In this study, air stripping for ammonia removal in synthetic wastewater and leachate was investigated under various operating conditions of $\mathrm{pH}$, initial ammonia concentration, hydraulic loading rate, gas to liquid ratio, and recirculating time. As a result, the increase of $\mathrm{pH}$ from 9 to 12 led to the significant increase of ammonia removal efficiency, irrespective of the changes of $\mathrm{G} / \mathrm{L}$ or HLR, with the highest ammonia stripping achieved at $\mathrm{pH} 12$. For both hydraulic loading rates of 57.6 and $172.8 \mathrm{~m}^{3} / \mathrm{m}^{2}$.day, rising $\mathrm{G} / \mathrm{L}$ ratio resulted in the improvement of removal efficiency, up to $56 \%$. Under the HLR of $172.8 \mathrm{~m}^{3} / \mathrm{m}^{2}$.day, $\mathrm{pH} 12, \mathrm{G} / \mathrm{L}$ of 728 with liquid recirculation, the leachate containing ammonia at $2520 \mathrm{mg} / \mathrm{L}$ was stripped out $99 \%$ of ammonia for three hours. The final concentration of ammonia was $25.2 \mathrm{mg} / \mathrm{L}$ which is about equal to the allowable value from the discharging standard of leachate. The results from this study hence proved the effectiveness of air stripping in ammonia removal from leachate and the optimum operating conditions were suggested. Further investigation is needed for recovery the amount of ammonia stripped and released into gas phase so that this gas stream can meet the requirement to discharge into the air.

\section{REFERENCES}

[1] P. Kjeldsen, M. A. Barlaz, A. P. Rooker, A. Baun, A. Ledin, and T. H. Christensen, "Present and longterm composition of MSW landfill leachate: a review," Critical reviews in environmental science and technology, vol. 32, pp. 297-336, 2002.

[2] A. Lopez, M. Pagano, A. Volpe, and A. C. Di Pinto, "Fenton's pre-treatment of mature landfill leachate," Chemosphere, vol. 54, pp. 1005-1010, 2004.

[3] D. Shiskowski and D. Mavinic, "Biological treatment of a high ammonia leachate: influence of external carbon during initial startup," Water Research, vol. 32, pp. 2533-2541, 1998.

[4] K. C. Cheung, L. M. Chu, and M. H. Wong, "Ammonia stripping as a pretreatment for landfill leachate," Water, air, and soil pollution, vol. 94, pp. 209-221, 1997.

[5] S. Marttinen, R. Kettunen, K. Sormunen, R. Soimasuo, and J. Rintala, "Screening of physical-chemical methods for removal of organic material, nitrogen and toxicity from low strength landfill leachates," Chemosphere, vol. 46, pp. 851-858, 2002. 
[6] I. Ozturk, M. Altinbas, I. Koyuncu, O. Arikan, and C. Gomec-Yangin, "Advanced physico-chemical treatment experiences on young municipal landfill leachates," Waste Management, vol. 23, pp. 441446, 2003.

[7] A. Ž. Gotvajn, T. Tišler, and J. Zagorc-Končan, "Comparison of different treatment strategies for industrial landfill leachate," Journal of Hazardous Materials, vol. 162, pp. 1446-1456, 2009.

[8] Ł. Jurczyk, J. Koc-Jurczyk, and A. Masłoń, "Simultaneous Stripping of Ammonia from Leachate: Experimental Insights and Key Microbial Players," Water, vol. 12, p. 2494, 2020.

[9] F. M. Ferraz, J. Povinelli, and E. M. Vieira, "Ammonia removal from landfill leachate by air stripping and absorption," Environmental Technology, vol. 34, pp. 2317-2326, 2013.

[10] V. K. Minocha and A. P. Rao, "Ammonia removal and recovery from urea fertilizer plant waste," Environmental Technology, vol. 9, pp. 655-664, 1988.

[11] A. Bonmatı and X. Flotats, "Air stripping of ammonia from pig slurry: characterisation and feasibility as a pre-or post-treatment to mesophilic anaerobic digestion," Waste management, vol. 23, pp. 261272, 2003.

[12] L. Zhang, Y.-W. Lee, and D. Jahng, "Ammonia stripping for enhanced biomethanization of piggery wastewater," Journal of hazardous materials, vol. 199, pp. 36-42, 2012.

[13] S. Guštin and R. Marinšek-Logar, "Effect of $\mathrm{pH}$, temperature and air flow rate on the continuous ammonia stripping of the anaerobic digestion effluent," Process safety and environmental protection, vol. 89, pp. 61-66, 2011.

[14] X. Lei, N. Sugiura, C. Feng, and T. Maekawa, "Pretreatment of anaerobic digestion effluent with ammonia stripping and biogas purification," Journal of hazardous materials, vol. 145, pp. 391-397, 2007.

[15] M. Á. De la Rubia, M. Walker, S. Heaven, C. J. Banks, and R. Borja, "Preliminary trials of in situ ammonia stripping from source segregated domestic food waste digestate using biogas: Effect of temperature and flow rate," Bioresource technology, vol. 101, pp. 9486-9492, 2010.

[16] S. K. Marttinen, R. H. Kettunen, K. M. Sormunen, R. M. Soimasuo, and J. A. Rintala, "Screening of physical-chemical methods for removal of organic material, nitrogen and toxicity from low strength landfill leachates," Chemosphere, vol. 46, pp. 851-858, 2002.

[17] M. Cotman and A. Ž. Gotvajn, "Comparison of different physico-chemical methods for the removal of toxicants from landfill leachate," Journal of Hazardous Materials, vol. 178, pp. 298-305, 2010.

[18] M. Nurisepehr, S. Jorfi, R. R. Kalantary, H. Akbari, R. D. C. Soltani, and M. Samaei, "Sequencing treatment of landfill leachate using ammonia stripping, Fenton oxidation and biological treatment," Waste Management \& Research, vol. 30, pp. 883-887, 2012.

[19] A. Silva, M. Dezotti, and G. L. Sant'Anna Jr, "Treatment and detoxification of a sanitary landfill leachate," Chemosphere, vol. 55, pp. 207-214, 2004.

[20] H. A. P. dos Santos, A. B. de Castilhos Júnior, W. C. Nadaleti, and V. A. Lourenço, "Ammonia recovery from air stripping process applied to landfill leachate treatment," Environmental Science and Pollution Research, vol. 27, pp. 45108-45120, 2020.

[21] R. Alam and M. D. Hossain, "Effect of Packing Materials and Other Parameters on the Air Stripping Process for the Removal of Ammonia from the Wastewater of Natural Gas Fertilizer Factory," Journal of Water Resource and Protection, vol. 01, pp. 210-215, 2009.

[22] V. Leite, S. Prasad, W. Lopes, J. Sousa, and A. Barros, "Study on ammonia stripping process of leachate from the packed towers," Journal of Urban and Environmental Engineering, vol. 7, pp. 215222, 2013.

[23] Metcalf and I. Eddy, Wastewater engineering: treatment and reuse, Fourth edition / revised by George Tchobanoglous, Franklin L. Burton, H. David Stensel. Boston: McGraw-Hill, 2003.

[24] V. Y. Hoang, H. Jupsin, V. C. Le, and J. L. Vasel, "Modeling of partial nitrification and denitrification in an SBR for leachate treatment without carbon addition," Journal of Material Cycles and Waste Management, vol. 14, pp. 3-13, 2012.

[25] M. K. Nguyen and T. Q. T. Hoang, "Chemical Precipitation of Ammonia and Phosphate from Nam Son Landfill Leachate, Hanoi," Iranian (Iranica) Journal of Energy \& Environment, vol. 3, pp. 32-36, 2012.

[26] T. T. N. Dieu, T. T. Canh, and J. L. Vasel, "Removal of cod and nitrogen in Leachate by using combined Anoxic/attached-growth bioreactor," Proceedings Sardinia 2017/ Sixteenth International Waste Management and Landfill Symposium, S. Margherita di Pula, Cagliari, Italy, 2017. 
[27] L. Son, N. Dan, P. Nhat, L. Tam, T. Sang, and L. Thanh, "Application of CANON-SBR process for ammonium removal from old municipal old landfill leachate," Science \& Technology Development Journal - Science of The Earth \& Environment, vol. 3, pp. 46-55, 2019.

[28] L. Khai, "Study on leachate treatment after electrocoagulation process by bio-filter system: a case study in Nam Son landfill, Ha Noi," Vietnam Journal of Science and Technology, vol. 55, p. 251, 2018.

[29] T. S. Le, N. M. Dang, and D. T. Tran, "Performance of coupling electrocoagulation and biofiltration processes for the treatment of leachate from the largest landfill in Hanoi, Vietnam: Impact of operating conditions," Separation and Purification Technology, vol. 255, 2021, Art. no. 117677, doi: https://doi.org/10.1016/j.seppur.2020.117677.

[30] N. T. Dung, B. Van Thanh, and N. N. Huy, "A study on the application of Fenton process followed by coagulation for treatment of landfill leachate," Vietnam Journal of Chemistry, vol. 58, pp. 792-797, 2020.

[31] S. Soda, D. Fujii, D. A, M. Ike, and V. Nguyen Trung, "Leachate treatment processes improve water quality in waste landfills in Ho Chi Minh City," Proceedings of the Annual Conference of Japan Society of Material Cycles and Waste Management, vol. 27, p. 551, 2016.

[32] A. C. Anthonisen, R. C. Loehr, T. B. S. Prakasam, and E. G. Srinath, "Inhibition of Nitrification by Ammonia and Nitrous Acid," Journal (Water Pollution Control Federation), vol. 48, pp. 835-852, 1976. 